ISSN : 2303-1514 | E-ISSN : 2598-5949

\title{
DIGITAL LITERACY: THE URGENCY OF DIGITAL SKILL IMPROVEMENT THROUGH E-MODULES
}

\author{
Kuncahyono $^{1}$, Dian Fitri Nur Aini ${ }^{2}$ \\ ${ }^{1,2}$ Program Studi PGSD FKIP Universitas Muhammadiyah Malang, Indonesia \\ ${ }^{1}$ kuncahyono@umm.ac.id, ${ }^{2}$ dianfitri@umm.ac.id
}

\section{LITERASI DIGITAL: URGENSI PENINGKATAN DIGITAL SKILL MELALUI E-MODUL}

\begin{tabular}{|c|c|}
\hline ARTICLE HISTORY & ABSTRACT \\
\hline $\begin{array}{l}\text { Submitted: } \\
12 \text { November } 2020 \\
12^{\text {th }} \text { November } 2020\end{array}$ & $\begin{array}{l}\text { Abstract: The purpose of this study was to describe the implementation of digital literacy using } \\
\text { e-modules and to increase the understanding of PGSD students. The type of this study was } \\
\text { Classroom Action Research (CAR). The subjects of this study were students of PGSD } \\
\text { Universitas Muhammadiyah Malang class of 2016, totaling } 50 \text { students. The implementation of } \\
\text { digital literacy skills using e-modules used } 3 \text { learning stages, namely: (a) software } \\
\text { engineering; (b) instructional design; and (c) the level of visual communication. Sources of } \\
\text { data in this study were students' work in developing students active learning (SAL) oriented } \\
\text { teaching materials, and the process of how students develop teaching materials by using } \\
\text { student active learning (SAL) oriented e-module guidelines in elementary schools. Sources of } \\
\text { data in this study were the SAL-based teaching materials designed by the students, and the } \\
\text { process of developing teaching materials using student active learning (SAL) oriented e- } \\
\text { module guidelines in elementary schools. The results of the study showed that students' } \\
\text { understanding of digital literacy skills included: 1) The use of SAL-based e-module guidelines } \\
\text { improved students' skills in compiling digital teaching materials. 2) The increase in students } \\
\text { skills in compiling digital teaching materials after using the e-module guidelines was marked } \\
\text { by the increase in student skills in compiling digital teaching materials from } 56.8 \% \text { to } 82.5 \% \text {. It } \\
\text { can be said that using e-module guidelines improved the students' skills in making digital- } \\
\text { based teaching materials. }\end{array}$ \\
\hline
\end{tabular}

Accepted:

01 Januari 2021

$01^{\text {st }}$ January 2021

Published:

20 Februari 2021

$20^{\text {nd }}$ February 2021

\section{Keywords: Digital Literacy, Digital Skill, E-module, Student Active Learning}

Abstrak: Tujuan penelitian ini untuk mendeskripsikan pelaksanaan literasi digital menggunakan e-modul serta peningkatan pemahaman mahasiswa mahasiswa PGSD. Jenis penelitian yang digunakan adalah Penelitian Tindakan Kelas (PTK). Subjek penelitian ini adalah mahasiswa PGSD Universitas Muhammadiyah Malang angkatan 2016 yang berjumlah 50 mahasiswa. Pelaksanaan literasi digitall skill menggunakan e-modul menggunakan 3 tahapan pembelajaran yaitu: (a) rekayasa perangkat lunak; (b) desain pembelajaran; dan (c) tingkat komunikasi visual. Sumber data dalam penelitian ini ialah hasil karya mahasiswa dalam mengembangkan bahan ajar berorientasi student active learning (SAL), dan proses bagaimana mahasiswa mengembangkan bahan ajar menggunakan pedoman e-modul berorientasi student active learning (SAL) pada Sekolah Dasar. Sumber data dalam penelitian ini ialah hasl bahan ajar mahasiswa berbasis student active learning (SAL), dan proses dalam mengembangkan bahan ajar menggunakan pedoman e-modul berorientasi student active learning (SAL) pada Sekolah Dasar. Hasil penelitian menujukkan peningkatan pemahamn literasi digital skill mahasiswa meliputi: 1) Penggunaan pedoman e-modul berbasis SAL dapat meningkatkan skill mahasiswa dalam menyusun bahan ajar digital. 2) Peningkatan skill mahasiswa dalam menyusun bahan ajar digital setelah menggunakan pedoman e-modul ditandai dengan meningkatnya skill mahasiswa dalam menyusun bahan ajar digital dari 56,8\% ke $82,5 \%$. Dapat dikatakan dengan menggunakan pedoman e-modul dapat meningkatkan keterampilan mahasiswa dalam membuat bahan ajar berbasis digital.

Kata Kunci: Literasi Digital, Digital Skill, E-modul, Student Active Learning

\section{CITATION}

Kuncahyono., \& Aini. D. F. N. (2021). Digital Literacy: The Urgency of Digital Skill Improvement through E-Modules. Primary: Jurnal Pendidikan Guru Sekolah Dasar, 10 (1), 94 - 101. DOI: http://dx.doi.org/10.33578/jpkip.v10i1.8098 


\section{PENDAHULUAN}

Proses pembelajaran dalam pendidikan di era masyarakat abad 21 adalah suatu interaksi antara guru dengan siswa sesuai dengan kemajuan ilmu pengetahuan dan teknologi dalam masyarakat yang demokratis dan terbuka (Depdiknas, 2001). Mulyana (2007) menyatakan bahwa guru seharusnya memiliki kompetensi yang memadai untuk melakukan tugas membimbing, membina, dan mengarahkan peserta didik dalam menumbuhkan semangat keunggulan, motivasi belajar, dan memiliki kepribadian serta budi pekerti luhur yang sesuai dengan budaya bangsa Indonesia. Dalam hal ini berarti guru pada abad 21 memiliki tantangan yang baru dalam proses pembelajaran. Guru dituntut untuk mampu memfasilitasi peserta didik dengan berbagai teknologi yang telah berkembang saat ini. Dalam hal ini dapat dijelaskan bahwa guru harus mampu mengenal teknologi, mengaplikasikan teknologi, dan mengembangkan produk-produk pembelajaran yang berintegrasi teknologi. Ketiga hal tersebut dapat menjadi salah satu kunci keberhasilan pembelajaran di abad 21.

Sebelum menjadi guru, calon guru juga harus memiliki kompetensi yang diharapkan di dunia pendidikan pada abad 21. Calon guru yang dimaksudkan adalah mahasiswa yang sedang menempuh Pendidikan di bidang keguruan dan ilmu Pendidikan, khususnya Pendidikan Sekolah Dasar. Mahasiswa calon guru SD diharapkan mampu membiaskan diri untuk mengenal serta mengembangkan inovasi pembelajaran berbasis teknologi guna memfasilitasi peserta didik di masa mendatang. Hal ini sejalan dengan generasi peserta didik yang akan diajar oleh mahasiswa calon guru SD yaitu generasi digital native. Digital native merupakan generasi yang lahir pada era digital (Prensky, 2001). Generasi digital natives lebih banyak mengisi kehidupan dengan penggunaan komputer, video games, digital music players, video cams, cell phone dan berbagai macam perangkat yang diproduksi di abad 21 . Mahasiswa calon guru diharapkan mampu menjadi pendidik dan fasilitator Pendidikan peserta didik generasi digital native dalam pelaksanaan pembelajaran.

Selain diharuskan memiliki kompetensi yang berhubungan dengan teknologi, guru pada abad 21 juga diwajibkan memfasilitasi kemampuan peserta didik dalam memahami pembelajaran yang disajikan. Dapat disimpulkan bahwa dalam pembelajaran guru tidak berpusat pada guru (teacher centered) namun lebih berpusat kepada peserta didik (student centered). Hal ini sejalan dengan pendapat (Suprihatiningrum, 2013) dalam pembelajaran di kelas, Student Active Learning (SAL) melibatkan peserta didik dalam melakukan dan berfikir tentang apa yang sedang dikerjakan dan melibatkan peserta didik baik secara fisik maupun mental (Turk, 2009).

Guna mendukung pelaksanaan pembelajaran yang memanfaatkan teknologi dan berpusat pada peserta didik, mahasiswa calon guru SD perlu memperoleh pengetahuan yang bekaitan dengan pengembangan media, bahan ajar, dan alat penilaian yang berbasis teknologi yang berpusat pada peserta didik. Keberadaan media, bahan ajar dan alat penilaian berbasis teknologi akan memotivasi peserta didik dalam meningkatkan pembelajaran yang berpusat pada peserta didik. Dalam pelaksanaan pembelajaran ketiga komponen tersebut memegang peranan penting dalam rangka meningkatkan kualitas pembelajaran di era 21. Berdasarkan hasil evaluasi dari kegiatan peerteaching mahasiswa PGSD menunjukkan bahwa mahasiswa belum bahan ajar yang inovatif dan berbasis teknologi. Data menunjukkan bahwa $31 \%$ mahasiswa calon guru SD belum menggunakan bahan ajar inovatif berbasis teknologi. Mahasiswa calon guru SD cenderung menyalin buku siswa yang telah banyak beredar di pasaran sehingga bahan ajar yang digunakan terkesan monoton dan tidak 
memberikan pengalaman baru bagi peserta didik. Lebih lanjut, 58\% mahasiswa calon guru sudah menggunakan bahan ajar namun cenderung merancang bahan ajar berupa hard file yang mengakibatkan peserta didik tidak tertarik dengan bahan ajar yang disajikan. Terdapat $11 \%$ mahasiswa calon guru yang menggunakan bahan ajar inovatif berbasis teknologi namun bahan ajar yang disajikan merupakan bahan ajar hasil rancangan dari ahli TIK dan untuk mendapatkannya membutuhkan biaya yang tidak sedikit. Meskipun rancangan ide berasal dari mahassiwa calon guru, namun keahlian mengembangkan bahan ajar berbasis teknologi belum dimiliki oleh mahasiswa calon guru dikarenakan pemahaman yang kurang terhadap aplikasi yang digunakan untuk menyusun bahan ajar berbasis teknologi.

Berdasarkan data yang telah disajikan dapat disimpulkan bahwa kemampuan mahasiswa calon guru SD dalam mengembangkan bahan ajar sangat rendah. Data menunjukkan $31 \%$ belum mampu merancang bahan ajar inovatif, 58\% sudah mampu menyusun bahan ajar namun belum memperhatikan sisi inovatif dan berbasis teknologi dan $11 \%$ sudah memiliki kemampuan merancang ide bahan ajar inovatif namun belum memiliki skill dalam menyusun bahan ajar inovatif berbasis teknologi.

$$
\text { Permasalahan yang telah }
$$

dideskripsikan dapat diberikan solusi berupa pedoman e-modul berorientasi student active learning (SAL) yang dapat digunakan oleh mahasiswa calon guru untuk memandu merancang bahan ajar berbasis teknologi yang sederhana. E-modul merupakan bahan ajar yang memuat konten teks, gambar, dan video dalam satu paket yang memudahkan pendidik dalam melakukan pembelajaran. Pedoman emodul berorientasi student active learning (SAL) adalah hasil penelitian yang telah diujicobakan pada guru SD di Kota Malang dan sudah memiliki Hak Karya Cipta (HKI). Pedoman e-modul berbasis student active learning diharapkan dapat meningkatkan kemampuan mahasiswa calon guru SD dalam mengembangkan bahan ajar berbasis teknologi, inovatif dan mampu mengaktifkan peserta didik dalam pembelajaran.

Melihat latar belakang yang telah dipaparkan, perlu adanya penanganan terkait peningkatan kemampuan mahasiswa dalam mengengembangkan bahan ajar yang berbasis teknologi dan mengakomodasi peserta didik untuk aktif dalam pembelajaran. Berdasarkan pemaparan tesebut tujuan penelitian ini yaitu mendeskripsikan pelaksanaan literasi digital menggunakan e-modul serta peningkatan pemahaman mahasiswa mahasiswa PGSD.

\section{METODE PENELITIAN}

Penelitian ini menggunakan jenis penelitian tindakan kelas dengan tujuan untuk memperbaiki mutu proses dan hasil pembelajaran di kelas, sehingga dapat meningkatkan keaktifan dan prestasi belajar mahasiswa. Subyek dalam penelitian ini adalah mahasiswa PGSD UMM angkatan tahun 2018 semester IV yang berjumlah 50 mahasiswa. Pelaksanaan penelitian tindakan kelas dilakukan secara bersiklus dengan tahapan perencanaan, pelaksanaan, pengamatan, dan relfeksi. Teknik pengumpulan data dengan observasi, wawancara, dokumentasi dan tes. Observasi diakukan dengan mengamati proses pembuatan bahan ajar oleh mahasiswa. Wawancara dilakukan untuk mengetahui kelebihan serta hambatan ketika membuat bahan ajar digital. Selanjutnya tes dilakukan untuk mengetahui hasil peningkatan keterampilan produk bahan ajar yang sudah dikembangan oleh mahasiswa. Penelitian ini dilakukan untuk meningkatkan kemampuan mahasiswa PGSD dalam mengembangkan bahan ajar menggunakan pedoman e-modul berorientasi student active learning (SAL). Penelitian Tindakan kelas ini dilakukan berdasarkan hasil data observasi dalam evaluasi kegiatan peerteaching mahasiswa PGSD terkait rendahnya kemampuan mahasiswa PGSD dalam mengembangkan bahan ajar. Penelitian ini dimaksudkan untuk mengatasi permasalahan mahasiswa terkait 
kemampuan mengembangkan bahan ajar yang rendah. Sumber data dalam penelitian ini ialah hasil karya mahasiswa dalam mengembangkan bahan ajar berorientasi student active learning (SAL), dan proses bagaimana mahasiswa mengembangkan bahan ajar menggunakan pedoman e-modul berorientasi student active learning (SAL) pada Sekolah Dasar.

\section{HASIL DAN PEMBAHASAN}

Penelitian ini dilaksanakan dalam dua siklus, dalam setiap siklus melalui tahapan perencanaan, tindakan, pengamatan dan refleksi.

1. Siklus 1

a. Perencanaan

Pelaksanaan siklus 1 diawali dengan merencanakan pembelajaran tentang materi yang akan dikembangkan dengan melakukan beberapa kegiatan, antara lain:

1) Mahasiswa diminta untuk membuat rancangan materi yang akan digunakan serta dikembangkan pada pembelajaran.

2) Mahasiswa diminta untuk mempersiapkan perlengkapan dan program aplikasi bahan ajar digital yang dikembangkan.

3) Mahasiswa diminta untuk menyiapkan instrumen-instrumen penelitian antara lain lembar observasi, soal-soal tes mahasiswa, pedoman wawancara, dan format catatan lapang.

b. Pelaksanaan

Pada tahap pelaksanaan, bertepatan dengan kondisi peningkatan kasus covid-19 sehingga pembelajaran dilakukan secara daring. Tahap pelaksanaan diawali dengan kegiatan dosen yang sekaligus berperan sebagai peneliti memberikan materi terkait pengembangan bahan ajar melalui conference yang dilakukan melalui LMS. Kelas yang digunakan peneliti yaitu kelas mata kuliah Pembelajaran IPA SD. Kelas tersebut diikuti oleh mahasiswa semester IV PGSD UMM. Materi yang diberikan kepada mahasiswa terkait pengembangan bahan ajar antara lain berkaitan dengan komponen bahan ajar, karakteristik bahan ajar untuk siswa SD, aplikasi pengembangan bahan ajar digital dan pemetaan KD dan pengembangan indikator untuk materi ajar. Setelah mendapatkan penjelasan dari dosen, mahasiswa diminta untuk mengembangkan bahan ajar digital sesuai dengan pemahaman masing-masing mahasiswa secara mandiri. Bahan ajar yang dikembangkan harus memuat komponen bahan ajar yang sudah dijelaskan dosen dalam kegatan converence.

c. Pengamatan

Kegiatan pengamatan pada tindakan siklus 1 dilakukan dengan mengamati aktivitas mahasiswa selama mengembangkan bahan ajar digital. Mahasiswa cenderung kurang melakukan inovasi pada bahan ajar digital yang dikembangkannya. Aplikasi yang dipilih mahasiswa dalam mengembangkan bahan ajar secara umum $80 \%$ menggunakan power point. Bahan ajar yang diletakkan dalam power point tidak efektif karena bahan ajar yang dikembangkan belum memuat seluruh indikator yang telah dikembangkan oleh mahasiswa. Selain itu, penambahan animasi dan sound belum dilakukan sehingga bahan ajar yang dikembangkan menjadi monoton dan kurang menarik bagi siswa SD.

\section{d. Refleksi}

Kegiatan refleksi terhadap pengamatan aktivitas penyusunan bahan ajar digital oleh mahasiswa pada siklus 1 menunjukkan bahwa aktivitas yang dilakukan mahasiswa dalam menyusun bahan ajar cenderung kurang inovatif dan belum memenuhi komponen yang harus ada dalam bahan ajar digital. Meskipun penjelasan yang sudah dilakukan oleh dosen sudah jelas dan runtut, namun mahasiswa mengalami kesulitan dalam memahami materi yang disampaikan. Selain itu, mahasiswa mengalami kendala terkait komponen yang harus termuat dalam bahan ajar digital. 
Tabel 1. Penilaian Bahan Ajar Siklus 1

\begin{tabular}{|c|c|c|c|}
\hline No & Aspek & Komponen & Rata-rata \\
\hline \multirow[t]{6}{*}{1} & $\begin{array}{l}\text { Rekayasa Perangkat } \\
\text { Lunak }\end{array}$ & $\begin{array}{l}\text { a. Efektif dan efisien dalam pengembangan maupun } \\
\text { penguasaan }\end{array}$ & 60.8 \\
\hline & & b. Usabilitas (mudah digunakan dalam & 61.5 \\
\hline & & pengoperasiannya) & 50.6 \\
\hline & & c. Maintainable (dapat dipelihara/dikelola dengan & 57.6 \\
\hline & & & \\
\hline & & Rata-rata & \\
\hline \multirow[t]{5}{*}{2} & Desain & a. Kesesuaian materi dengan tujuan pembelajaran & 63.3 \\
\hline & Pembelajaran & b. Sistematis dan runtut & 60.2 \\
\hline & & c. Pemberian motivasi belajar & 55.7 \\
\hline & & d. Kejelasan uraian, pembahasan, dan latihan & 57.4 \\
\hline & & Rata-rata & 59.15 \\
\hline \multirow[t]{8}{*}{3} & Komunikasi Visual & $\begin{array}{l}\text { a. Komunikatif, sesuai dengan pesan dan dapat diterima } \\
\text { dengan keinginan sasaran }\end{array}$ & 60.6 \\
\hline & & b. Kreatif dalam ide & 54.7 \\
\hline & & c. Sederhana dan memikat & 53.9 \\
\hline & & d. Audio (narasi, sound effect, backsound, music) & 51.8 \\
\hline & & e. Development visual (layout design, typography, & 50.8 \\
\hline & & warna) & 50.15 \\
\hline & & f. Media bergerak (animasi, movie) & 53.65 \\
\hline & & Rata-rata & \\
\hline
\end{tabular}

2. Siklus 2

a. Perencanaan

Dengan memperhatikan refleksi tindakan pada siklus 1, kegiatan perencanaan dilakukan dengan melalui beberapa kegiatan berikut:

1) Dosen mempersiapkan pedoman e-modul berbasis SAL dalam bentuk softcopy.

2) Dosen memberikan softcopy pedoman emodul berbasis SAL berupa link yang ada pada LMS.

3) Mahasiswa mengunduh pedoman e-modul berbasis SAL pada LMS masing-masing mahasiswa secara mandiri.

4) Dosen menyiapkan link conference yang ada pada LMS untuk pelaksaanaan pembelajaran pada siklus 2 .

b. Pelaksanaan

Pelaksanaan tindakan pada siklus 2 dimulai dengan kegiatan conference oleh dosen dan mahasiswa pada LMS yang sudah disiapakn pada tahap perencanaan. Dosen memberikan pengantar dan penjelasan kepada mahasiswa terkait pedoman e-modul yang dapat digunakan oleh mahasiswa untuk mengembangkan bahan ajar digital. Pada tahap pelaksanaan, dosen juga menjelaskan tahapantahapan dalam megembangkan bahan ajar digital berdasarkan pedoman yang sudah didownload oleh mahasiswa pada LMS. Pada saat menjelaskan, mahasiswa diminta untuk menyimak pedoman e-modul masing-masing yang telah dimilikinya. Selanjutnya, mahasiswa diminta untuk mengembangkan bahan ajar digital berupa modul digital menggukan pedoman e-modul yang telah dimiliki oleh masing-masing mahasiswa.

c. Pengamatan

Dari pelaksanaan siklus 2 didapatkan pengamatan terkait aktivitas mahasiswa dalam menyusun bahan ajar digital menunjukkan peningkatan dari inovasi, ragam, kelengkapan komponen, desain, dan kemudahan penggunaan e-modul yang dikembangkan. Komponen yang harus ada pada modul sudah tercapai sekitar $90 \%$ dari total siswa dalam kelas. Selain itu, inovasi yang dilakukan juga beragam dan memuat gambar serta suara yang dapat menarik minat siswa SD untuk menggunakan modul yang telah dikembangkan. 
d. Refleksi

Dari pengamatan yang dilakukan pada siklus 2 dapat direfleksikan bahwa terjadi peningkatan aktivitas dan skill mahasiswa dalam menyusun bahan ajar digital menggunakan pedoman e-modul berbasis SAL. Dari dua siklus yang telah dilakukan menunjukkan bahwa pedoman e-modul dapat membantu mahasiswa dalam menyusun bahan ajar digital yang saat ini diperlukan pada era 4.0.Penelitian ini dilaksanakan dalam dua siklus. Secara lengkap data hasil penilaian bahan ajar digital mahasiswa dipaparkan dalam tabel 3 di bawah ini.

Tabel 2. Penilaian Bahan Ajar Siklus 2

\begin{tabular}{|c|c|c|c|c|}
\hline No & Aspek & Komponen & Siklus I & Siklus II \\
\hline \multirow[t]{4}{*}{1} & $\begin{array}{l}\text { Rekayasa } \\
\text { Perangkat Lunak }\end{array}$ & $\begin{array}{l}\text { a. Efektif dan efisien dalam } \\
\text { pengembangan maupun penguasaan }\end{array}$ & 60.8 & 87.45 \\
\hline & & $\begin{array}{l}\text { b. Usabilitas (mudah digunakan dalam } \\
\text { pengoperasiannya) }\end{array}$ & 61.5 & 84.7 \\
\hline & & $\begin{array}{l}\text { c. Maintainable (dapat } \\
\text { dipelihara/dikelola dengan mudah) }\end{array}$ & 50.6 & 75.6 \\
\hline & & Rata-rata & 57.6 & 82.5 \\
\hline \multirow[t]{6}{*}{2} & Desain & a. Kesesuaian materi dengan tujuan & 63.3 & 73.6 \\
\hline & Pembelajaran & pembelajaran & 60.2 & 88.9 \\
\hline & & b. Sistematis dan runtut & 55.7 & 85.2 \\
\hline & & c. Pemberian motivasi belajar & 57.4 & 87.1 \\
\hline & & $\begin{array}{l}\text { d. Kejelasan uraian, pembahasan, dan } \\
\text { latihan }\end{array}$ & 59.15 & 83.7 \\
\hline & & Rata-rata & & \\
\hline \multirow[t]{8}{*}{3} & $\begin{array}{l}\text { Komunikasi } \\
\text { Visual }\end{array}$ & $\begin{array}{l}\text { a. Komunikatif, sesuai dengan pesan dan } \\
\text { dapat diterima dengan keinginan }\end{array}$ & 60.6 & 80.3 \\
\hline & & sasaran & 54.7 & 87.6 \\
\hline & & b. Kreatif dalam ide & 53.9 & 75.8 \\
\hline & & c. Sederhana dan memikat & 51.8 & 81.9 \\
\hline & & $\begin{array}{l}\text { d. Audio (narasi, sound effect, } \\
\text { backsound, music) }\end{array}$ & 50.8 & 83.9 \\
\hline & & $\begin{array}{l}\text { e. Development visual (layout design, } \\
\text { typography, warna) }\end{array}$ & 50.15 & 78.5 \\
\hline & & f. Media bergerak (animasi, movie) & & \\
\hline & & Rata-rata & $\mathbf{5 3 . 6 5}$ & 81.3 \\
\hline
\end{tabular}

Tabel 3. Nilai rata-rata gabungan siklus I dan II

\begin{tabular}{|c|c|c|c|c|}
\hline No & Aspek & Komponen & Siklus I & Siklus II \\
\hline \multirow[t]{4}{*}{1} & Rekayasa & d. Efektif dan efisien dalam & 60.8 & 87.45 \\
\hline & Perangkat Lunak & $\begin{array}{l}\text { pengembangan maupun penguasaan } \\
\text { e. Usabilitas (mudah digunakan dalam } \\
\text { pengoperasiannya) }\end{array}$ & 61.5 & 84.7 \\
\hline & & $\begin{array}{l}\text { f. Maintainable (dapat dipelihara/dikelola } \\
\text { dengan mudah) }\end{array}$ & 50.6 & 75.6 \\
\hline & & Rata-rata & 57.6 & 82.5 \\
\hline \multirow[t]{4}{*}{2} & Desain & e. Kesesuaian materi dengan tujuan & 63.3 & 73.6 \\
\hline & Pembelajaran & pembelajaran & 60.2 & 88.9 \\
\hline & & f. Sistematis dan runtut & 55.7 & 85.2 \\
\hline & & g. Pemberian motivasi belajar & 57.4 & 87.1 \\
\hline
\end{tabular}




\begin{tabular}{|c|c|c|c|c|}
\hline No & Aspek & Komponen & Siklus I & Siklus II \\
\hline & & $\begin{array}{l}\text { h. Kejelasan uraian, pembahasan, dan } \\
\text { latihan }\end{array}$ & 59.15 & 83.7 \\
\hline & & Rata-rata & & \\
\hline \multirow[t]{10}{*}{3} & \multirow{10}{*}{$\begin{array}{l}\text { Komunikasi } \\
\text { Visual }\end{array}$} & g. Komunikatif, sesuai dengan pesan dan & 60.6 & 80.3 \\
\hline & & dapat diterima dengan keinginan sasaran & & \\
\hline & & h. Kreatif dalam ide & 54.7 & 87.6 \\
\hline & & i. Sederhana dan memikat & 53.9 & 75.8 \\
\hline & & j. Audio (narasi, sound effect, backsound, & 51.8 & 81.9 \\
\hline & & music) & 50.8 & 83.9 \\
\hline & & k. Development visual (layout design, & & \\
\hline & & typography, warna) & 50.15 & 78.5 \\
\hline & & 1. Media bergerak (animasi, movie) & 53.65 & 81.3 \\
\hline & & Rata-rata & & \\
\hline
\end{tabular}

Dari tabel dapat dijelaskan bahwa pada siklus I terlihat aktivitas dan skill penyusunan bahan ajar digital cenderung kurang, yaitu aspek rekayasa perangkat lunak sebesar $57.6 \%$, desain pembelajaran sebesar $59.15 \%$ serta komunikasi visual sebesar $53.65 \%$. Pada siklus I mahasiswa cenderung belum begitu inovatif dalam menyusun bahan ajar digital. Selain itu, aplikasi yang digunakan secara umum menggunakan power point, penggunaan power point mengakibatkan materi yang disajikan terlalu sempit dan belum mengakomodasi seluruh indikator yang dikembangkan dalam pembelajaran. Komponen bahan ajar juga belum sepenuhnya dilengkapi oleh mahasiswa pada saat menyusun bahan ajar digital. Terkait dengan aspek komunikasi visual, mahasiswa cenderung kurang melakukan modifikasi dengan bahan ajar yang dilakukan. Dari refleksi pada siklus I maka dosen melakukan siklus II dengan menggunakan pedoman emodul sebagai alat yang dapat digunakan mahasiswa agar lebih mudah menyusun bahan ajar digital berupa e-modul.

Pada siklus II terjadi peningkatan skill mahaisswa yaitu aspek rekayasa perangkat lunak sebesar $82.5 \%$, desain pembelajaran sebesar $83.7 \%$ dan komunikasi visual sebesar $81.3 \%$. Pada siklus II dosen menggunakan pedoman e-modul sebagai alat yang digunakan untuk membantu mahasiswa menyusun bahan ajar digital. Pedoman e-modul dapat membantu dan menuntun mahasiswa dalam menyusun bahan ajar digital dalam bentuk emodul. Pada saat menggunakan pedoman emodul, mahasiswa cenderung lebih terampil dalam menyusun bahan ajar karena di dalam pedoman e-modul dilengkapi contoh yang dapat menginspirasi mahasiswa untuk mngembangkan ide lain dari contoh yang telah dilihatnya. Selain itu, pedoman e-modul juga dapat digunakan secara mandiri oleh mahasiswa sehingga mahasiswa tidak memerlukan waktu untuk bertanya kepada dosen terkait kesulitan yang dialaminya. Dapat dikatakan bahwa proses belajar mengajar lebihefektif dan efesien melalui bahan ajar yang sudah dikembangkan.

\section{SIMPULAN DAN REKOMENDASI}

Hasil penelitian dan pembahasan yang telah dilakukan, dapat disimpulkan:Penggunaan pedoman e-modul berbasis SAL dapat meningkatkan skill mahasiswa dalam menyusun bahan ajar digital. Peningkatan skill mahasiswa dalam menyusun bahan ajar digital setelah menggunakan pedoman e-modul berbasis SAL ditandai dengan meningkatnya skill mahasiswa dalam menyusun bahan ajar digital dari 56.8\% ke $82.5 \%$. Rekomendasi yang dapat diberikan dalam hasil penelitian ini yaitu keterampilan digital mahasiswa dapat ditingkatkan melalui penggunaan pedoman e-modul dengan mengintegrasikan model pembelajaran student active learning. Sebaiknya produk yang 
dihasilkan dapat digunakan dalam pembelajaran di kelas besar atau diseminasi produk ke lapangan.

\section{DAFTAR PUSTAKA}

Ariani, N., \& Dany, H. (2010). Pembelajaran Multimedia di Sekolah Pedoman Pembelajaran Inspiratif, Konstruktif, dan Prospektif. Jakarta: PT Prestasi Pustakarya.

Depdiknas. (2001). Peningkatan Mutu Pendidikan Di Sekolah Dasar. Jakarta.

Sanjaya, W. (2005). Pembelajaran dalam Implementasi Kurikulum Berbasis Kompetensi, Kencana Prenada. Jakarta: Media Group.

Saputro, A. (2009). Pengembangan Modul Elektronik Untuk Mata Kuliah DasarDasar Fotografi, Skripsi Jurusan Kurikulum dan Teknologi PendidikanUniversitas Negeri Jakarta.

Siagian, S. (2014). Development of basic electronic instructional Module and trainer. European Journal of Computer Science and information technology, Vol.2,No.3,pp.36-46. Diakses tanggal 31 Januari 2019, http://www.eajournals.org/wpcontent/uploads/Development-ofBasic-Electronic-Instructional.pdf.

Suprihatiningrum, J. (2013). Strategi Pembelajaran Teori \& Aplikasi. Jogjakarta: Ar-Ruzz Media.

Turk, M. (2009). Utjecaj aktivnog učenja u visokoškolskoj nastavi na razvoj stvaralaštva budućih nastavnika. In L. Bognar (Ed.), Poticanje stvaralaštva u odgoju i obrazovanju (pp. 107-115). Zagreb: Profil International.

Prensky M. (2001) Digital Natives, Digital Immigrant. On the Horizon. (MCB University Press) Vol.9(5). Part1. http://www.marcprensky.com/writing/ pr ensky\%20\%20digital\%20natives, $\% 20$ digit al \%20immigrants\%20\%20part1.pdf [diakses 10 September 2019]. 